\title{
Bioavailability of Organic Phosphorus Compounds to the Harmful Dinoflagellate Karenia mikimotoi
}

\author{
Kaixuan Huang, Yanqing Zhuang, Zhou Wang, Linjian Ou *, Jingyi Cen, Songhui Lu and Yuzao Qi
}

Citation: Huang, K.; Zhuang, Y.; Wang, Z.; Ou, L.; Cen, J.; Lu, S.; Qi, Y. Bioavailability of Organic

Phosphorus Compounds to the Harmful Dinoflagellate Karenia mikimotoi. Microorganisms 2021, 9 , 1961. https://doi.org/10.3390/ microorganisms 9091961

Academic Editor: Giovanni Vallini

Received: 18 August 2021

Accepted: 13 September 2021

Published: 15 September 2021

Publisher's Note: MDPI stays neutral with regard to jurisdictional claims in published maps and institutional affiliations.

Copyright: (c) 2021 by the authors. Licensee MDPI, Basel, Switzerland. This article is an open access article distributed under the terms and conditions of the Creative Commons Attribution (CC BY) license (https:/ / creativecommons.org/licenses/by/ $4.0 /)$.
Research Center of Harmful Algae and Marine Biology, Key Laboratory of Eutrophication and Red Tide Prevention of Guangdong Higher Education Institutes, Jinan University, Guangzhou 510632, China; babyblue02@126.com (K.H.); zzyq7722@163.com (Y.Z.); Wangzhou@126.com (Z.W.); jingyicen@foxmail.com (J.C.); lusonghui1963@126.com (S.L.); tq1@jnu.edu.cn (Y.Q.)

* Correspondence: torangeou@jnu.edu.cn

\begin{abstract}
Karenia mikimotoi is one of the most well-known harmful bloom species in temperate coastal waters. The present study investigated the characteristics of alkaline phosphatase (APase) and phosphodiesterase (PDEase) activities in hydrolysis of two phosphomonoesters (adenosine triphosphate (ATP) and ribulose 5-phosphate (R5P)) and a phosphodiester (cyclic adenosine monophosphate (cAMP)) in K. mikimotoi and compared its growth and physiological responses to the different forms of phosphorus substrates. K. mikimotoi produced comparable quantities of APase and PDEase to hydrolyze the organic phosphorus substrates, although hydrolysis of the phosphomonoesters was much faster than that of the phosphodiester. The growth of K. mikimotoi on organic phosphorus substrates was comparable to or better than that on inorganic phosphate. The difference in particulate organic nutrients (carbon, nitrogen, and phosphorus) and hemolytic activity supported different rates of hydrolysis-assimilation of the various organic phosphorus substrates by K. mikimotoi. The hemolytic activities of K. mikimotoi in the presence of organic phosphorus substrates were several times those in the presence of inorganic phosphate during the exponential phase. This suggested the potential important role of organic phosphorus in K. mikimotoi blooms.
\end{abstract}

Keywords: Karenia mikimotoi; phosphatase; dinoflagellate

\section{Introduction}

Karenia mikimotoi is one of the most well-known harmful bloom-causing species in temperate coastal waters around the world [1-3]. K. mikimotoi can produce various toxic substances, such as hemolytic compounds [1,4], cytotoxins [3,5], and reactive oxygen species $[3,6]$, and can thus cause massive mortality of both wild and cultured fish and shellfish. In East Asia, especially in China and Japan, the frequency of K. mikimotoi blooms has increased greatly in recent years [7,8]. Blooms caused by K. mikimotoi accounted for $65.2 \%$ and $31.5 \%$ of HAB case numbers associated with fishery damage in China and western Japan, respectively, during 1978-2018 [9]. In China, K. mikimotoi blooms have occurred frequently in the coastal waters of Fujian and Zhejiang provinces in the East China Sea since 2002 [8,9]. The most severe damage caused by K. mikimotoi ever recorded was reported in the coastal waters of Fujian Province with estimated economic losses exceeding 300 million US dollars in 2012 [3,8]. In 2017, K. mikimotoi blooms in the coastal waters of Zhejiang Province lasted for more than one month, affecting an area larger than 1200 square kilometers [10]. The occurrence frequency of K. mikimotoi blooms in Japan in 2012-2018 was approximately four times that in 1999-2011 [7]. Blooms of K. mikimotoi caused cultured fish mortality with approximate economic losses of 15.3 million US dollars in the Bungo Channel in 2012 [11]. An extensive K. mikimotoi bloom caused mass mortality of aquaculture fishes, leading to severe loss in Imari Bay in 2017 [7]. Consequently, numerous investigations have been carried out to study the physiology [12-15] and toxicology [4-6,16,17] of K. mikimotoi and to analyze the occurrence mechanism of $K$. mikimotoi blooms [7,11,18,19]. However, 
K. mikimotoi blooms are highly variable in location, timing, duration, and magnitude and do not occur every year, and the ecological processes involved in K. mikimotoi bloom formation remain largely obscure.

Nutrient availability is crucial to bloom formation, duration, and magnitude [20]. Some K. mikimotoi blooms have been connected to high terrestrial nutrient inputs after rainfall $[7,19]$. However, there is another contradictory opinion that abundant nutrients might not be necessary for the formation of K. mikimotoi blooms [1,3]. In contrast, an environment with relatively low nutrients might benefit $K$. mikimotoi due to competing with other species (such as diatoms) and surviving at relatively low densities, and its strong motility might make this species aggregate in layers allowing outburst under certain conditions [1]. It should be noted that the increasing frequency of K. mikimotoi blooms aligns with the varying nutrient structure in the coastal waters of East Asia in recent years. Due to the rapid development of the human population and the concomitant increase in industrial and agricultural activities, the unbalanced input of nitrogen $(\mathrm{N})$ and phosphorus $(\mathrm{P})$ into coastal waters has caused an obvious increase in the N:P ratio in East Asia [21,22]. Phytoplankton normally suffer P deficiency in late spring and summer in this area [21]. Blooms of K. mikimotoi have been observed in seawater with a high N:P ratio and a low phosphate concentration [18,23]. Furthermore, K. mikimotoi blooms can persist under phosphate-depleted conditions for more than one month [14]. The ability of K. mikimotoi to survive and grow under low-phosphate conditions might be crucial to bloom formation and duration.

$\mathrm{P}$ is a necessary biogenetic element for phytoplankton growth [24]. The dissolved organic $\mathrm{P}$ (DOP) pool is a major contributor to the presence of $\mathrm{P}$ in seawater, especially when external phosphate becomes depleted [25]. Phytoplankton that have advantages in utilizing DOP are competitive in phosphate-depleted environments [26]. Phosphomonoesters (PMEs) and phosphodiesters (PDEs) are the most abundant DOP compounds in natural seawater [24]. Previous studies showed that K. mikimotoi is capable of utilizing a wide variety of organic P substrates (both PMEs and PDEs) as a sole P source for growth $[27,28]$. Organic P contributes to outbreaks of K. mikimotoi blooms in eutrophic coastal waters $[3,27,28]$. However, Richardson and Corcoran [12] suggested that axenic K. mikimotoi could not utilize PDEs. To date, the characteristics of phosphomonoesterases (PMEases) and phosphodiesterases (PDEases), which play crucial roles in hydrolyzing PMEs and PDEs, respectively [24,26], have been rarely analyzed in terms of K. mikimotoi, especially for PDEases. It is uncertain whether K. mikimotoi has the relevant phosphatases to hydrolyze both PMEs and PDEs and what the hydrolysis efficiency of various DOP compounds by different phosphatases is in K. mikimotoi. In addition, whether different physiological and biochemical responses exist in utilizing various forms of DOP in K. mikimotoi is largely unknown. In the present study, K. mikimotoi was inoculated onto different P-containing substrates (two PMEs, one PDE, and one inorganic phosphate) as a sole P source. The roles of two extracellular phosphatases (PMEase and PDEase) in the hydrolysis of DOP and the growth and physiological metabolic response (particulate nutrients, pigment contents, and hemolytic activity) of $K$. mikimotoi were studied. The objectives of the study were to analyze the efficiency of phosphatases in hydrolyzing PMEs and PDEs, compare the utilization strategies of K. mikimotoi on different forms of P substrates, and demonstrate the potential importance of various organic P sources, thereby explaining the P nutritional physiology and ecology of K. mikimotoi blooms.

\section{Materials and Methods}

\subsection{Culture and Growth Conditions}

The K. mikimotoi strain (No. HK-5) was maintained in the Algal Collection at the Research Center of Harmful Algae and Marine Biology, Jinan University, China. Prior to the experiment, the cultures were reinoculated 2 times during the exponential phase in an Aquil artificial seawater medium (enriched with $\mathrm{f} / 2$ ) [29], and the phosphate concentration in the medium was gradually reduced from 36 to $6 \mu \mathrm{mol} \mathrm{P} \mathrm{L}{ }^{-1}$. The cultures were maintained at $21 \pm 1{ }^{\circ} \mathrm{C}$ under a light dark cycle of 12:12 $\mathrm{h}$ with a photosynthetically active 
radiation of $100 \mu \mathrm{mol}$ photon $\mathrm{m}^{-2} \mathrm{~s}^{-1}$. Antibiotics (penicillin $\mathrm{G}, 200 \mu \mathrm{g} \mathrm{mL}^{-1}$, streptomycin sulfate, $100 \mu \mathrm{g} \mathrm{mL}-1$, and kanamycin sulfate, $100 \mu \mathrm{g} \mathrm{mL}^{-1}$ ) were added in the medium $48 \mathrm{~h}$ before the next inoculation in order to eliminate bacterial contamination. The swimming behavior was checked to ascertain good physiological activity of K. mikimotoi using a light microscope (Olympus CX31, Tokyo, Japan). In addition, the cultures were checked for bacterial contamination with 4',6-diamidino-2-pheny-lindole (DAPI) (Sigma Inc., St. Louis, MO, USA) stain at regular intervals using an epifluorescence microscope (OLYMPUS X61, Tokyo, Japan).

Cells of K. mikimotoi in the exponential phase were reinoculated into P-free medium. When the concentration of dissolved inorganic P (DIP) in the medium was below the detection limit $\left(0.10 \mu \mathrm{mol} \mathrm{P} \mathrm{L}{ }^{-1}\right)$, the culture was placed in the dark for $4 \mathrm{~h}$ and then a LED white light lamp $(5 \mathrm{~W})$ was placed on the top of the culture. Cells that concentrated on the top layer of the medium by phototaxis were pipetted and diluted with fresh sterile artificial seawater to an initial density of approximately $3.0 \times 10^{3}$ cells $\mathrm{mL}^{-1}$. Four $\mathrm{P}$ substrates $\left(\mathrm{NaH}_{2} \mathrm{PO}_{4}, \mathrm{ATP}\right.$, ribulose 5-phosphate (R5P), and cyclic adenosine monophosphate (cAMP)) were added separately at a final concentration of $3.0 \mu \mathrm{mol} \mathrm{P} \mathrm{L}^{-1}$ in triplicate (hereafter referred to as ' $\mathrm{NaH}_{2} \mathrm{PO}_{4}$ ', 'ATP', 'R5P', and 'cAMP' treatments). Other nutrients were added according to the $\mathrm{f} / 2$ medium [30]. Samples for cell density and nutrient analyses were collected every other day, whereas samples to determine the maximum potential quantum efficiency of photosystem II ( Fv/ Fm), two phosphatase activities, particulate nutrients, pigments, and hemolytic activity were collected on days $0,4,8,12$, and 16 based on growth curves. Samples were obtained during the hours of 12:00 a.m.-13:00 p.m.

\subsection{Cell Counts and Fv/Fm Analyses}

Cells were fixed in a $\%$ acid Lugol's solution. K. mikimotoi samples were placed in a Palmer-Maloney counting chamber $(0.1 \mathrm{~mL})$ and counted using the light microscope. The specific growth rate $(\mu)$ of $K$. mikimotoi was calculated according to the equation $\mu=\left(\ln N_{2}-\ln N_{1}\right) /\left(t_{2}-t_{1}\right)$, where $N_{2}$ and $N_{1}$ are the cell densities at times $t_{2}$ and $t_{1}$, respectively. For the analysis of $\mathrm{Fv} / \mathrm{Fm}, 1 \mathrm{~mL}$ of sample was measured with a Phyto-PAM Phytoplankton Analyzer (Walz, Effeltrich, Germany) after dark adaptation for $5 \mathrm{~min}$.

\subsection{Nutrient Analyses}

Seawater was filtered through precombusted $\left(450{ }^{\circ} \mathrm{C}, 2 \mathrm{~h}\right) \mathrm{GF} / \mathrm{F}$ filters. The DIP content was determined using the molybdenum blue method described by Valderrama [31]. The total dissolved P (TDP) content was analyzed according to the method of Jeffries et al. [32], employing acid potassium persulfate $\left(\mathrm{K}_{2} \mathrm{~S}_{2} \mathrm{O}_{8}\right)$. The DOP content was calculated by subtracting the DIP from the TDP. The detection limits of both DIP and DOP were $0.10 \mu \mathrm{mol} \mathrm{L}^{-1}$.

Particulate organic carbon (POC) and particulate organic N (PON) were determined using a CHNS Elementar analyzer (PerkinElmer Series 2200, Boston, MA, USA), whereas particulate organic P (POP) was analyzed according to Solórzano and Sharp [33].

\subsection{Alkaline Phosphatase (APase) Activity and PDEase Activity Analyses}

APase activity (APA) and PDEase activity (PDEA) were measured by monitoring the release of paranitrophenol from $1 \mathrm{mmol} \mathrm{L}^{-1}$ paranitrophenylphosphatase (NPP) and $1 \mathrm{mmol} \mathrm{L}^{-1}$ bis-NPP, respectively, at $405 \mathrm{~nm}$ using a spectrophotometer (Hitachi U-4600, Tokyo, Japan) [34]. Seawater was unfiltered or filtered through 0.22 and $2 \mu \mathrm{m}$ polycarbonate filters under $<100 \mathrm{~mm} \mathrm{Hg}$ pressure; and, thus, APA and PDEA were divided into three size fractions: free-sized, $<0.22 \mu \mathrm{m}$, picosized, $0.22-2 \mu \mathrm{m}$ and nanosized, $>2 \mu \mathrm{m}$. The subsamples were incubated in the dark at $30^{\circ} \mathrm{C}$ for $24 \mathrm{~h}$. Sterile artificial seawater containing different substrates was used as the control. Calibration was performed with the standard solutions of NPP and bis-NPP in the range of $0.01-100 \mu \mathrm{mol} \mathrm{L}^{-1}$. 


\subsection{Pigment Analyses}

Aliquots of 30-50 mL of dinoflagellate cultures were filtered through precombusted GF/F filters. Pigments were extracted with $\mathrm{N}, \mathrm{N}$-dimethylformamide in a freezer $\left(-20^{\circ} \mathrm{C}\right)$ for $2 \mathrm{~h}$, and the extracts were filtered through $0.22-\mu \mathrm{m}$ polycarbonate filters (Millipore, Darmstadt, Germany) to remove cell debris. Pigment concentrations were measured using a Shimadzu LC20A-DAD HPLC system fitted with a $3.5 \mu \mathrm{m}$ Eclipse XDB C 8 column $(100 \times 4.6 \mathrm{~mm}$; Agilent Technologies, Santa Clara, CA, USA) according to the method presented by Zapata et al. [35]. The HPLC system was calibrated with 26 authentic pigment standards from the Danish Hydraulic Institute Water and Environment (Hørsholm, Denmark), which included chlorophyll $a(\mathrm{Chl} a)$, chlorophyll $b$, chlorophyll $c_{2}\left(\mathrm{Chl} c_{2}\right)$, chlorophyll $c_{3}\left(\mathrm{Chl} c_{3}\right)$, chlorophyllide $a$, divinyl $\mathrm{Chl} a$, magnesium 2,4-divinylpheoporphyrin a monomethyl ester, pheophytin $a$, pheophorbide $a, \beta, \beta$-carotene, $\beta, \varepsilon$-carotene, alloxanthin, antheraxanthin, 19'-butanoyloxyfucoxanthin, canthaxanthin, diadinoxanthin, diatoxanthin, echinenone, fucoxanthin, 19'-hexanoyloxyfucoxanthin, lutein, neoxanthin, peridinin, prasinoxanthin, violaxathin, and zeaxanthin.

\subsection{Hemolytic Activity Analyses}

The hemolytic activity was analyzed following the method presented by Eschbach et al. [36]. Aliquots of $10 \mathrm{~mL}$ of dinoflagellate cultures were centrifuged at $3000 \times g$ for $10 \mathrm{~min}$. The cells were resuspended in erythrocyte lysis buffer (Eschbach et al., 2001) and ultrasonicated. Fresh red blood cells of Japanese White Rabbits obtained from the Guangzhou Ruite Biological Technology Company (Guangzhou, China) were washed three times with phosphate-buffered saline $(\mathrm{pH} 7.4)$ and adjusted to a final concentration of $0.6 \%(v / v)$. Equal volumes of $150 \mu \mathrm{L}$ of algal samples and erythrocyte suspension were mixed and incubated under an irradiance of $100 \mu \mathrm{mol}$ photon $\mathrm{m}^{-2} \mathrm{~s}^{-1}$ at $20^{\circ} \mathrm{C}$ for $5 \mathrm{~h}$. For the negative control (zero hemolysis), erythrocytes were incubated in phosphate-buffered saline buffer alone. For the positive control ( $100 \%$ hemolysis), erythrocytes were incubated with $1 \% v / v$ Triton X-100. Following incubation, the mixed samples were centrifuged at $3000 \times g$ for $10 \mathrm{~min}$, and the supernatants were transferred to 96-well plates. Absorption was measured at $414 \mathrm{~nm}$ using a microplate reader (HBS-1096B, Detie Co., Ltd., Nanjing, China). The hemolytic activity was expressed as the percentage of hemolysis relative to both the positive and negative controls according to the equation: hemolytic activity $(\%)=(\mathrm{As}-\mathrm{Ab}-\mathrm{Aa}) / \mathrm{Ac} \times 100 \%$, where $\mathrm{As}, \mathrm{Ab}, \mathrm{Aa}$ and $\mathrm{Ac}$ represent the absorption of the experimental samples (algal samples incubated with erythrocytes), algal samples (algal samples incubated with erythrocyte buffer), negative control, and positive control, respectively.

\subsection{Data Analysis}

One-way ANOVA with Tukey's test was performed to compare the differences among treatments for each test parameter. A $p$ value $<0.05$ was considered significant. Prior to the analysis, the data were tested for normality and homogeneity of variation. A Log 10 or square-root transformation of the data was performed prior to any statistical test, when necessary. Statistical analyses were performed using SPSS 19.0 software (SPSS Inc., Chicago, IL, USA).

\section{Results}

\subsection{DIP and DOP Variations}

DIP decreased sharply from $2.92 \pm 0.09 \mu \mathrm{mol} \mathrm{L}^{-1}$ to approximately $0.10 \mu \mathrm{mol} \mathrm{L}^{-1}$ in the first two days and was below the detection limit thereafter in the $\mathrm{NaH}_{2} \mathrm{PO}_{4}$ treatment (Figure 1a). DIP increased to $0.51-0.65 \mu \mathrm{mol} \mathrm{L}^{-1}$ in the first few days and then decreased to lower than $0.10-0.20 \mu \mathrm{mol} \mathrm{L}^{-1}$ after day 12 in the ATP, R5P, and cAMP treatments. 

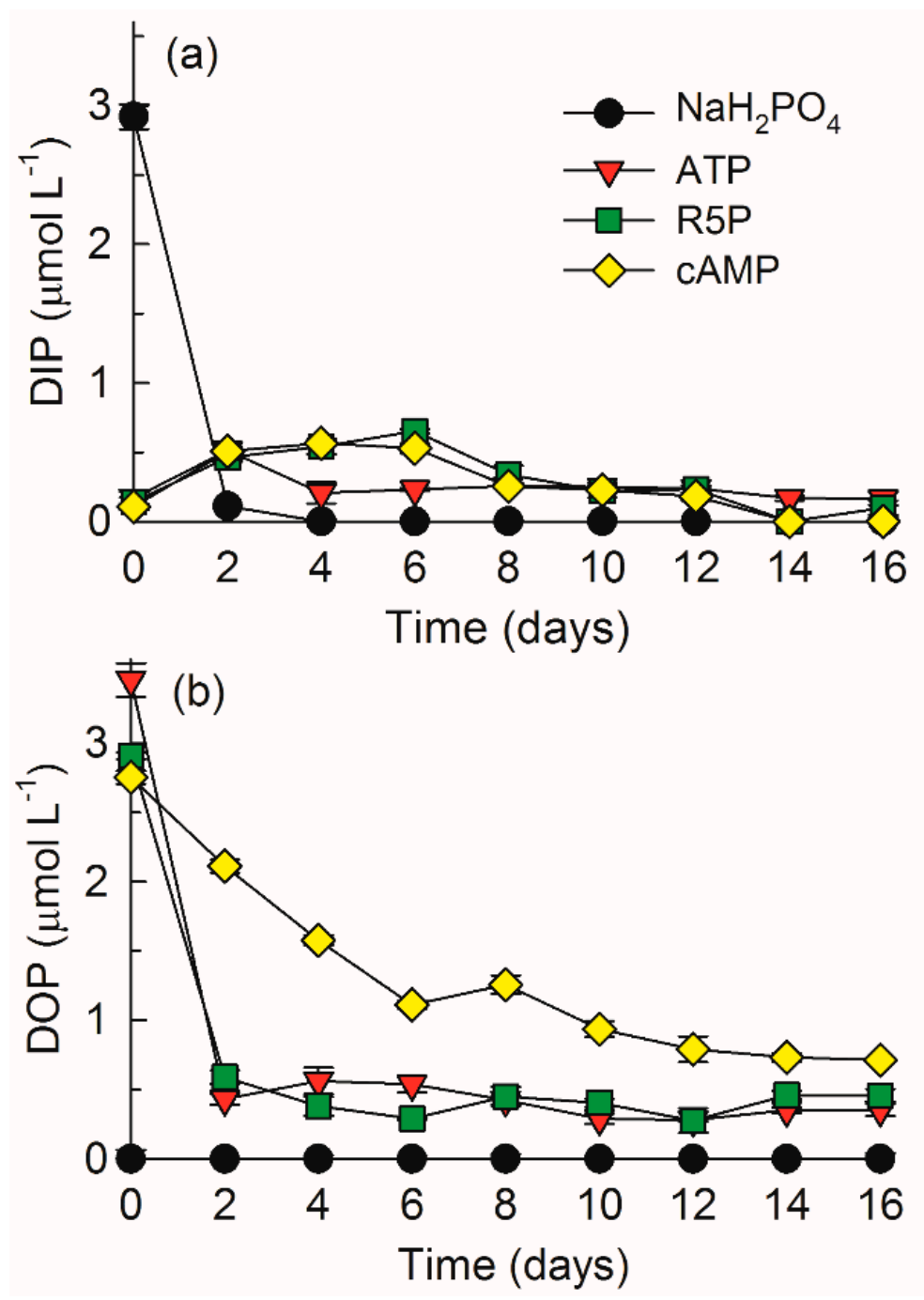

Figure 1. Concentrations of dissolved inorganic phosphorus (DIP) (a) and dissolved organic phosphorus (DOP) (b) in the $\mathrm{NaH}_{2} \mathrm{PO}_{4}$, adenosine triphosphate (ATP), ribulose 5-phosphate (R5P), and cyclic adenosine monophosphate (cAMP) treatments. The values are the mean \pm S.D. $(n=3)$.

DOP was undetectable in the $\mathrm{NaH}_{2} \mathrm{PO}_{4}$ treatment during the whole study (Figure $1 \mathrm{~b}$ ). DOP decreased sharply from $3.46 \pm 0.12 \mu \mathrm{mol} \mathrm{L}^{-1}$ and $2.91 \pm 0.02 \mu \mathrm{mol} \mathrm{L}^{-1}$ to approximately $0.50 \mu \mathrm{mol} \mathrm{L}^{-1}$ in the first two days and fluctuated thereafter in the respective ATP and R5P treatments. In contrast, in the cAMP treatment, DOP decreased gradually from $2.75 \pm 0.05 \mu \mathrm{mol} \mathrm{L}-1$ at the beginning to $0.71 \pm 0.01 \mu \mathrm{mol} \mathrm{L}-1$ at the end of the experiment.

\subsection{Growth and Fv/Fm}

K. mikimotoi cells grew slowly and entered the stationary phase on days $10,12,12$, and 16 in the $\mathrm{NaH}_{2} \mathrm{PO}_{4}, \mathrm{ATP}, \mathrm{R} 5 \mathrm{P}$, and cAMP treatments, respectively (Figure 2a). The maximum density in the $\mathrm{NaH}_{2} \mathrm{PO}_{4}$ treatment was comparable to that in the cAMP treatment $(p>0.05)$ but was significantly lower than those in the ATP and R5P treatments $(p<0.01)$ (Figure $2 \mathrm{~b}$ ). The average $\mu$ varied between $0.05-0.12 \mathrm{~d}^{-1}$, with much higher values in the R5P and ATP treatments $(p<0.05)$ (Figure 2c). 


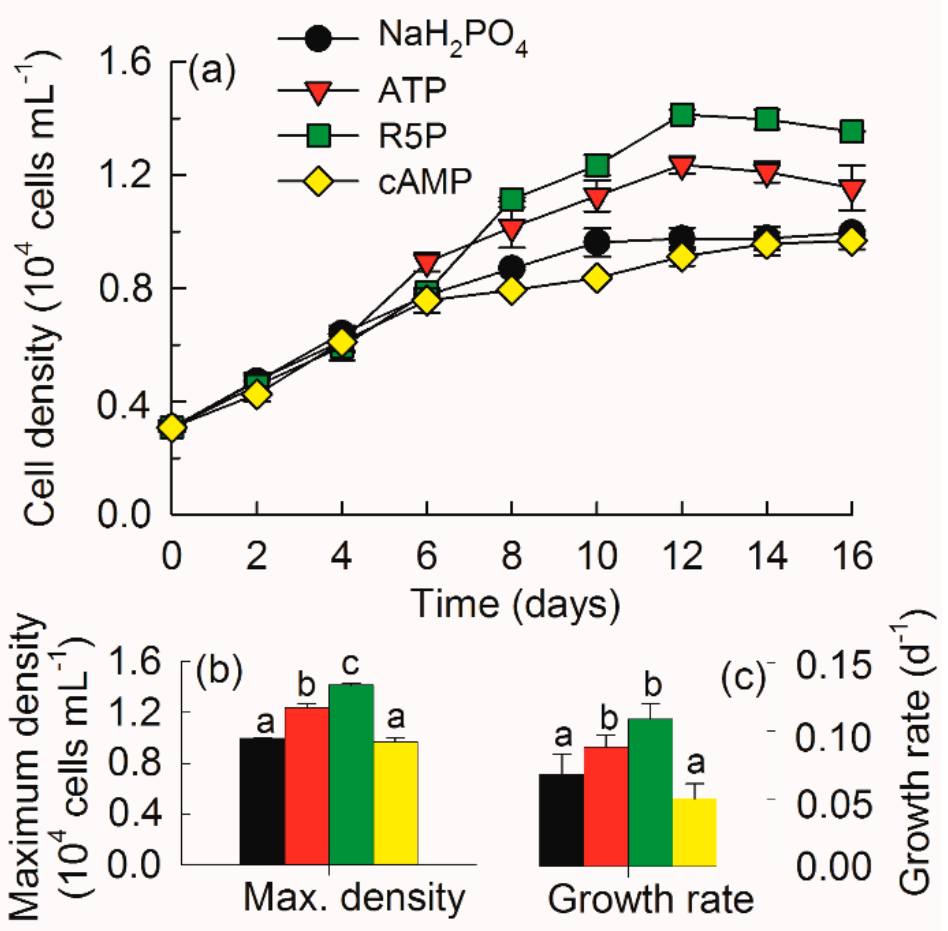

Figure 2. Growth curve (a), maximum cell density (b), and average growth rate $(\mu)$ (c) of Karenia mikimotoi in the $\mathrm{NaH}_{2} \mathrm{PO}_{4}$, adenosine triphosphate (ATP), ribulose 5-phosphate (R5P), and cyclic adenosine monophosphate (cAMP) treatments. The values are the mean \pm S.D. $(n=3)$. Significant differences $(p<0.05)$ among different phosphorus substrates are shown with different lowercase letters.

Fv/Fm varied between 0.52-0.72 during the whole study among all treatments (Figure 3). Fv/Fm in the $\mathrm{NaH}_{2} \mathrm{PO}_{4}$ treatment was significantly lower than that in any other DOP treatment after day $4(p<0.05)$. Among the DOP treatments, Fv/Fm in the ATP treatment increased markedly and reached the highest value on day $16(p<0.01)$.

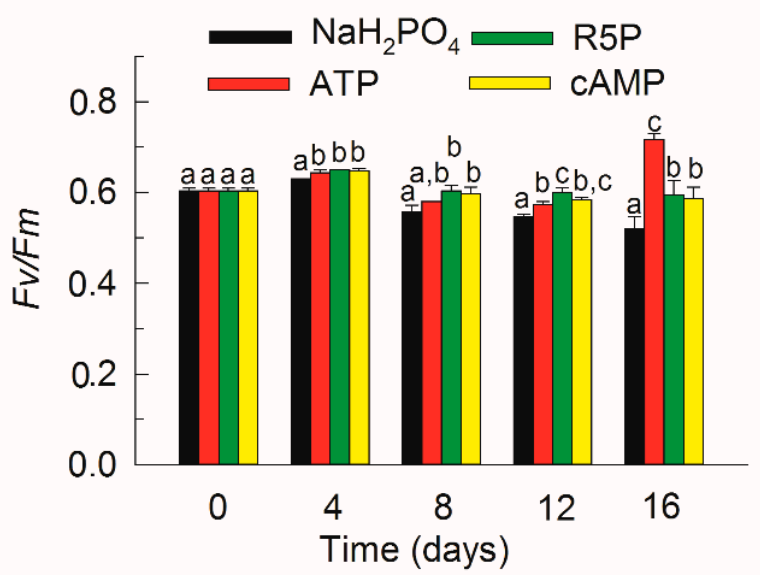

Figure 3. Fv/Fm of Karenia mikimotoi in the $\mathrm{NaH}_{2} \mathrm{PO}_{4}$, adenosine triphosphate (ATP), ribulose 5phosphate (R5P), and cyclic adenosine monophosphate (cAMP) treatments on days $0,4,8,12$, and 16 . The values are the mean \pm S.D. $(n=3)$. Significant differences $(p<0.05)$ among different phosphorus substrates are shown with different lowercase letters.

\subsection{APA and PDEA}

Total APA increased gradually in all treatments but showed some difference in the increasing trends (Figure $4 \mathrm{a}$ ). The total APA in the $\mathrm{NaH}_{2} \mathrm{PO}_{4}$ treatment was significantly 
higher than that in any other treatment before day $8(p<0.05)$, but the total APA in the R5P treatment was the highest thereafter, especially in the final days $(p<0.05)$. The total APA decreased in the order of $\mathrm{NaH}_{2} \mathrm{PO}_{4} \geq \mathrm{R} 5 \mathrm{P} \geq \mathrm{cAMP}>\mathrm{ATP}$ on day 8 , whereas the order changed to $\mathrm{R} 5 \mathrm{P}>\mathrm{NaH}_{2} \mathrm{PO}_{4}=$ ATP $>$ cAMP on day 16. Free-sized APA accounted for less than $10 \%$ of the total APA in all treatments during the whole experiment (Figure $4 \mathrm{c}$ ). Picosized APA contributed 74\% of the total APA on day 0 . However, nanosized APA increased greatly and contributed $50-80 \%$ of the total APA during the later period, except for a value of $40 \%$ in the ATP treatment on day 16.
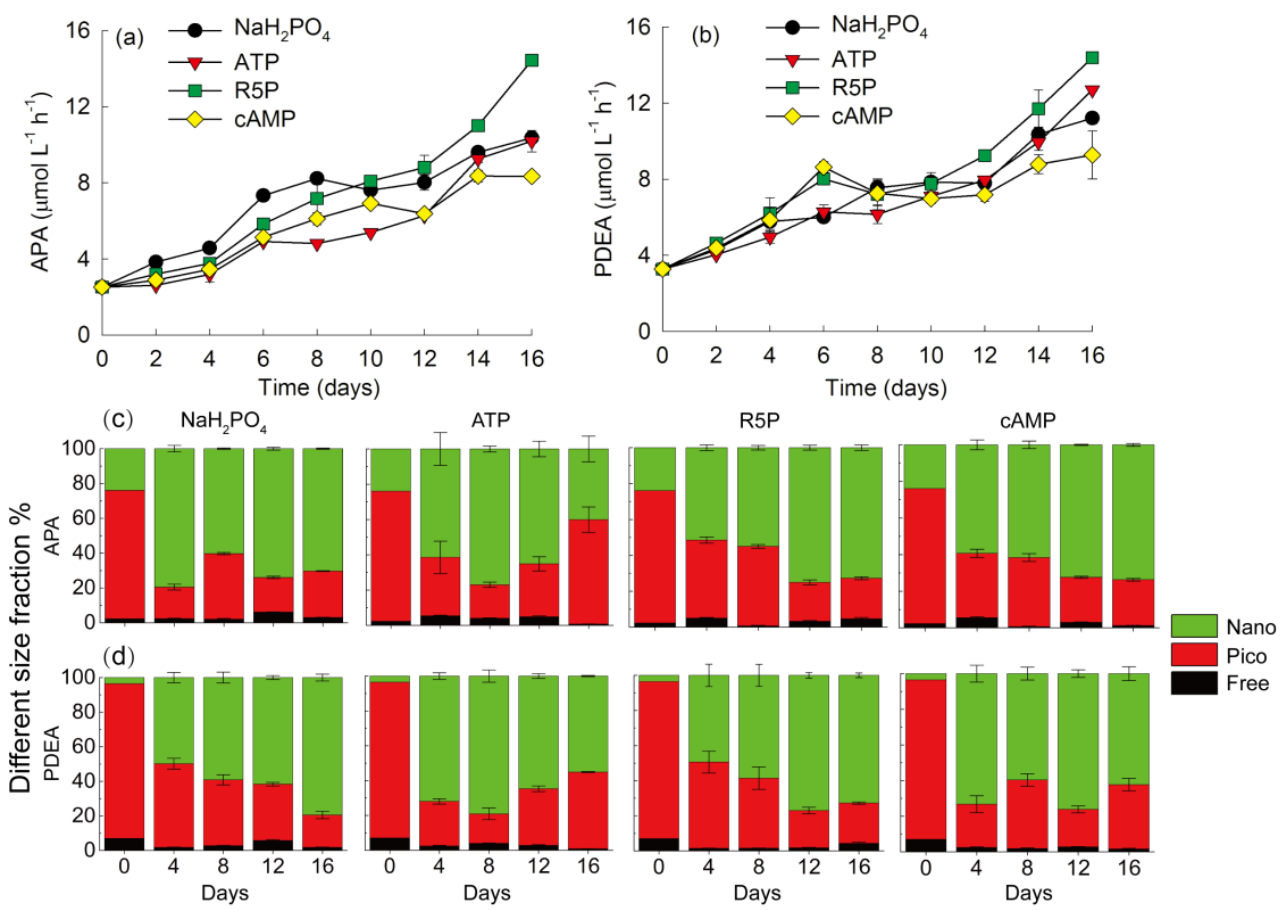

Figure 4. Alkaline phosphatase activity (APA) (a) and phosphodiesterase activity (PDEA) (b) and different size fractions of APA (c) and PDEA (d) of Karenia mikimotoi in the $\mathrm{NaH}_{2} \mathrm{PO}_{4}$, adenosine triphosphate (ATP), ribulose 5-phosphate (R5P), and cyclic adenosine monophosphate (cAMP) treatments. APA and PDEA are divided into three size fractions: free-sized, $<0.22 \mu \mathrm{m}$, picosized, $0.22-2 \mu \mathrm{m}$, and nanosized, $>2 \mu \mathrm{m}$. The values are the mean \pm S.D. $(n=3)$.

The values of PDEA were comparable to those of APA during the experiment. The total PDEA in the $\mathrm{NaH}_{2} \mathrm{PO}_{4}, \mathrm{ATP}$, and R5P treatments increased gradually with time, whereas the total PDEA in the cAMP treatment reached its first peak on day 6, decreased by $6-20 \%$ on days $8-12$ and then increased to its peak value on days 14 and 16 (Figure 4b). The total PDEA in the cAMP and R5P treatments was comparable $(p>0.05)$ but was 1.3-1.4 times those in the $\mathrm{NaH}_{2} \mathrm{PO}_{4}$ and ATP treatments $(p<0.01)$ on day 6 . At the end of the experiment, the total PDEA in the cAMP treatment was significantly lower than that in any other treatment $(p<0.05)$. Additionally, the total PDEA in the $\mathrm{NaH}_{2} \mathrm{PO}_{4}$ treatment was significantly lower than that in the R5P treatment $(p<0.01)$. Free-sized PDEA accounted for $1-7 \%$ of the total PDEA during the whole experiment (Figure $4 \mathrm{~d}$ ). Picosized PDEA contributed $89 \%$ of the total PDEA on day 0 , but nanosized PDEA was the greatest contributor thereafter (varying between $48-84 \%$ ).

\subsection{Particulate Nutrients}

POC varied from $80.3 \pm 6.5$ to $135.2 \pm 4.1$ pmol C cells $^{-1}$ among the treatments (Figure 5a). POC decreased by $20-30 \%$ on day 4 and showed no difference among the treatments. Thereafter, POC increased markedly with time except in the R5P treatment. The POC in the CAMP treatment was significantly higher than that in any other treatment on 
days 8 and $12(p<0.01)$. On day 16 , the POC in the $\mathrm{NaH}_{2} \mathrm{PO}_{4}$, ATP and cAMP treatments was comparable but was 1.3-1.4 times that in the R5P treatment $(p<0.01)$.
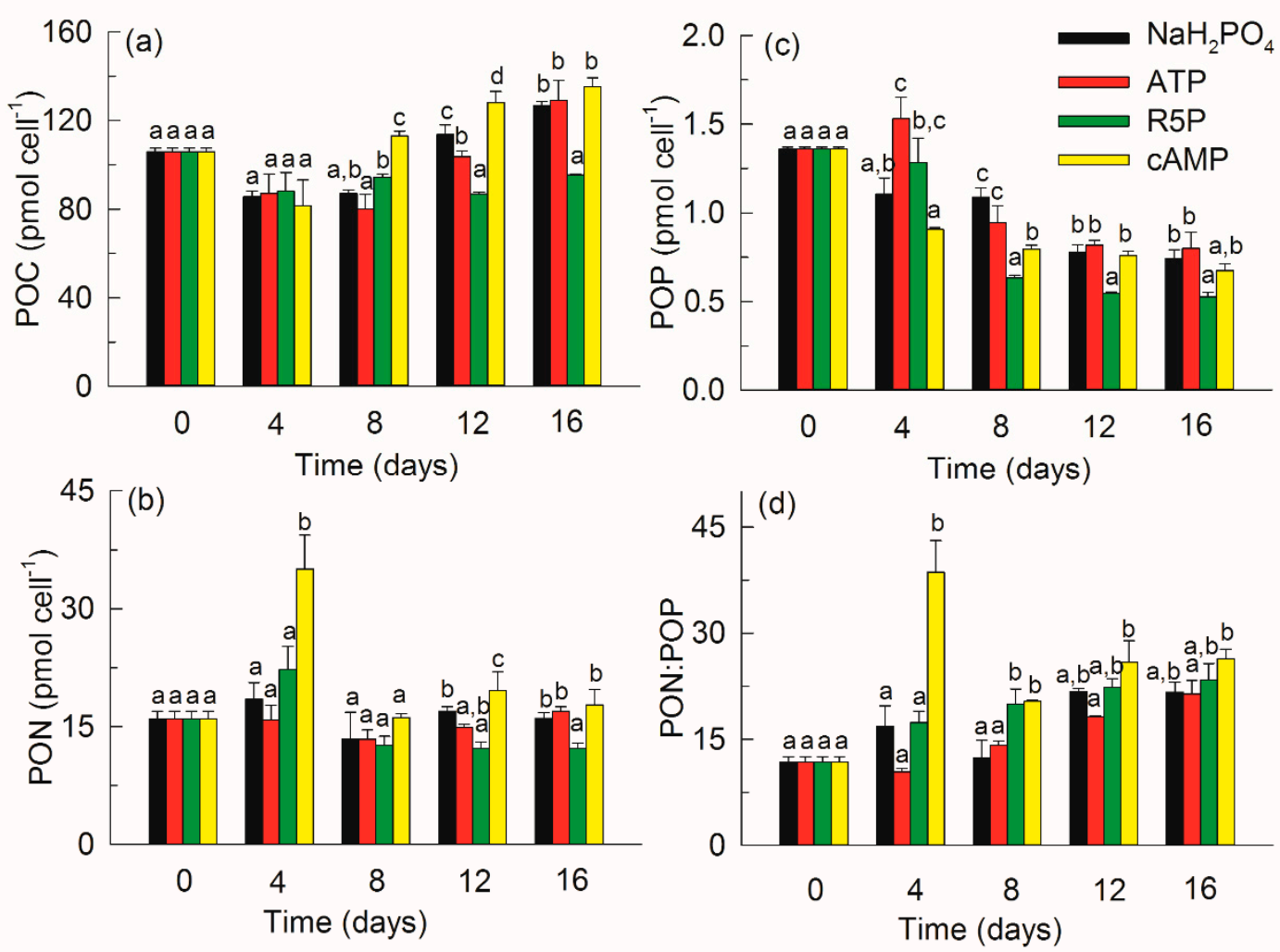

Figure 5. Particulate organic carbon (POC) (a), particulate organic nitrogen (PON) (b), particulate organic phosphorus (POP) (c), and PON:POP ratio (d) of Karenia mikimotoi in the $\mathrm{NaH}_{2} \mathrm{PO}_{4}$, adenosine triphosphate (ATP), ribulose 5-phosphate (R5P), and cyclic adenosine monophosphate (cAMP) treatments on days $0,4,8,12$, and 16 . The values are the mean \pm S.D. $(n=3)$. Significant differences $(p<0.05)$ among different phosphorus substrates are shown with different lowercase letters.

PON varied from $13.4 \pm 1.2$ to $35.1 \pm 4.3$ pmol N cells $^{-1}$ among the treatments (Figure $5 b$ ). PON increased greatly in the cAMP treatment on day 4, with a value 1.6-2.2 times that in the $\mathrm{NaH}_{2} \mathrm{PO}_{4}, \mathrm{ATP}$, and R5P treatments $(p<0.01)$, but decreased markedly to become comparable with the other treatments on day 8 . The PON in the R5P treatment was the lowest compared with the other treatments on days 12 and 16 .

POP varied from $0.53 \pm 0.02$ to $1.53 \pm 0.12$ pmol P cells $^{-1}$ among the treatments (Figure 5c). POP decreased gradually with time except in the ATP treatment on day 4 . The POP in the ATP treatment was approximately 1.2-1.7 times that in any other treatment on day 4. In the later period, the POP values in the $\mathrm{NaH}_{2} \mathrm{PO}_{4}$, ATP and cAMP treatments were comparable but significantly higher than that in the R5P treatment $(p<0.01)$.

The initial PON: POP ratio was 11.8 (Figure 5d). The PON:POP ratio in the cAMP treatment increased sharply to $38.6 \pm 4.5$ on day 4 , and then decreased to $20.4 \pm 0.2$ on day 8 . In the later period, the PON:POP ratios in all treatments increased gradually. The PON:POP ratios in the R5P and cAMP treatments were comparable but significantly higher than that in the ATP treatment $(p<0.05)$.

\subsection{Pigments}

A total of 13 pigments were measured in K. mikimotoi (Figure 6). Chl $a$, Chl $c_{2}$, and $\mathrm{Chl} c_{3}$ contributed $44.5-66.6 \%$ of the total pigments during the whole experiment (Figure 7). Fucoxanthin (19.9-36.8\%) was detected as the most abundant carotenoid in K. mikimotoi, followed by diadinoxanthin (2.6-9.7\%), 19'-butanoyloxyfucoxianthin (1.5-4.6\%), 19'-hexanoyloxyfucoxanthin (0.9-2.7\%), $\beta, \varepsilon$-carotene $(0.8-2.2 \%)$, and $\beta, \beta$-carotene $(0.1-1.0 \%)$. Lutein, zeaxanthin, alloxanthin, and diatoxanthin were detected in trace 
amounts of less than $1 \%$. The diagnostic fucoxanthin:Chl $a$ ratio ranged between $0.33-1.75$, but showed no difference between treatments on the same day. The fucoxanthin:Chl $a$ ratio on day 12 was significantly higher than those observed on days 0,4 , and 8 in the $\mathrm{NaH}_{2} \mathrm{PO}_{4}$ treatment $(p<0.05)$ (Figure 8).

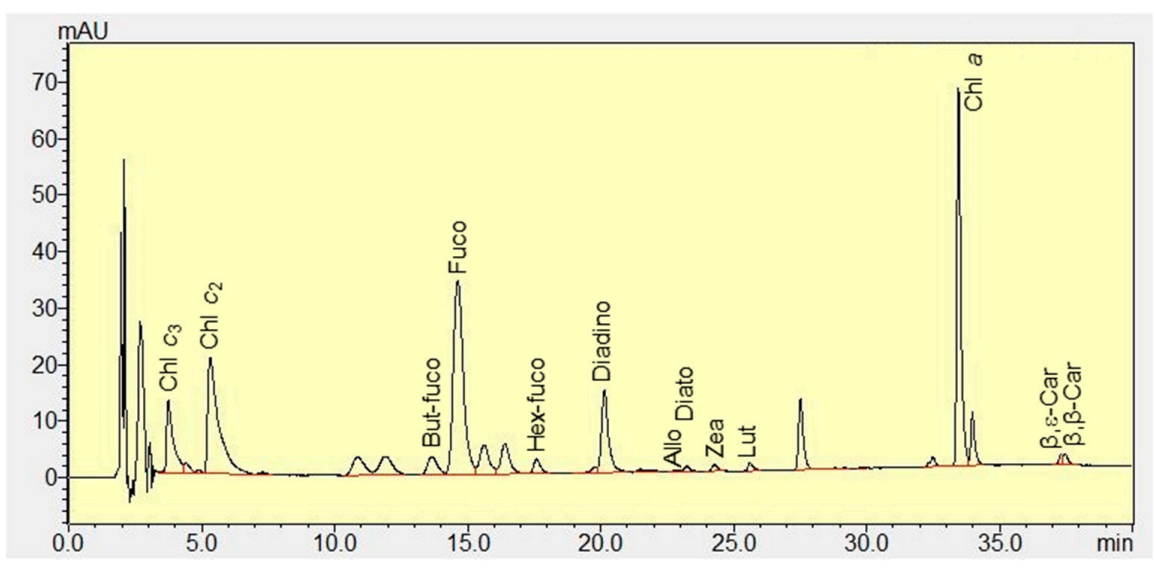

Figure 6. Pigment profiles of Karenia mikimotoi analyzed through HPLC. A total of 13 pigments is observed: chlorophyll $c_{3}\left(\mathrm{Chl} c_{3}\right)$, chlorophyll $c_{2}\left(\mathrm{Chl} c_{2}\right), 19^{\prime}$-butanoyloxyfucoxanthin (But-fuco), fucoxanthin (Fuco), 19'-hexanoyloxyfucoxanthin (Hex-fuco), diadinoxanthin (Diadino), alloxanthin (Allo), diatoxanthin (Diato), zeaxanthin (Zea), lutein (Lut), chlorophyll $a(\mathrm{Chl} a), \beta, \varepsilon$-carotene $(\beta, \varepsilon$ Car), and $\beta, \beta$-carotene $(\beta, \beta$-Car).

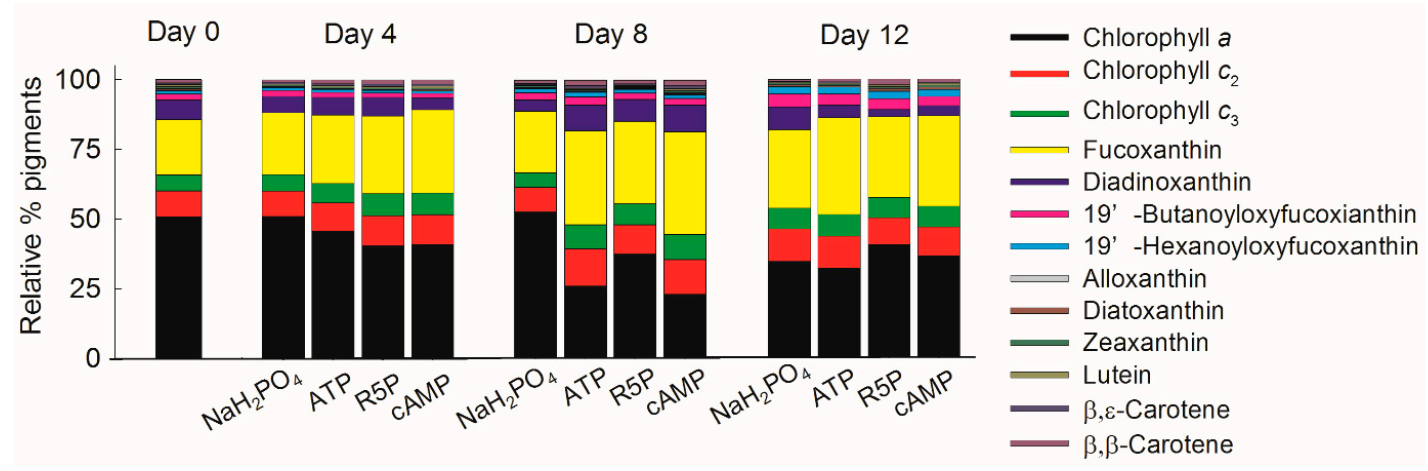

Figure 7. Pigment composition of Karenia mikimotoi in the $\mathrm{NaH}_{2} \mathrm{PO}_{4}$, adenosine triphosphate (ATP), ribulose 5-phosphate (R5P), and cyclic adenosine monophosphate (cAMP) treatments on days $0,4,8$, and 12.

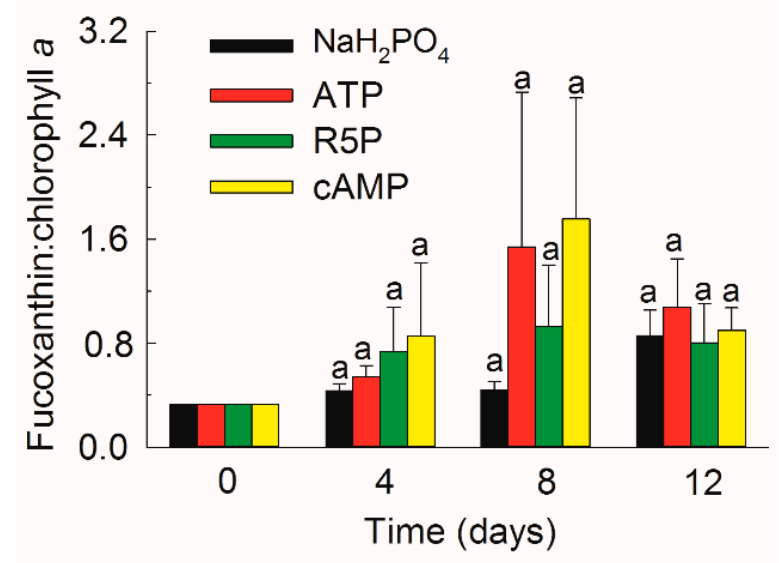

Figure 8. Ratio of fucoxanthin:chlorophyll $a$ in the $\mathrm{NaH}_{2} \mathrm{PO}_{4}$, adenosine triphosphate (ATP), ribulose 5-phosphate (R5P), and cyclic adenosine monophosphate (cAMP) treatments on days 0, 4, 8, and 12. The values are the mean \pm S.D. $(n=3)$. 
The cellular content of $\mathrm{Chl} a$ decreased significantly with time in all treatments $(p<0.01$ or $<0.05)$ (Figure 9). Additionally, chlorophyll $c_{2}$ and chlorophyll $c_{3}$ in the $\mathrm{NaH}_{2} \mathrm{PO}_{4}$ and R5P treatments on the initial days 0 and/or 4 were significantly higher than those on day $12(p<0.01$ or $<0.05)$. The contents of fucoxanthin and diadinoxanthin did not vary with time $(p>0.05)$, except that the fucoxanthin content on day 4 was approximately twice that on day 12 in the cAMP treatment $(p<0.05)$. At most times, the pigment contents did not show differences among the treatments $(p>0.05)$, except that the cellular content of $\mathrm{Chl} a$ in the $\mathrm{NaH}_{2} \mathrm{PO}_{4}$ treatment was approximately twice that in any other treatment on day $8(p<0.05)$ and the cellular contents of $\mathrm{Chl} c_{2}, \mathrm{Chl} c_{3}$, and fucoxanthin in the cAMP treatment were significantly higher than those in the other treatments on day $12(p<0.05)$.
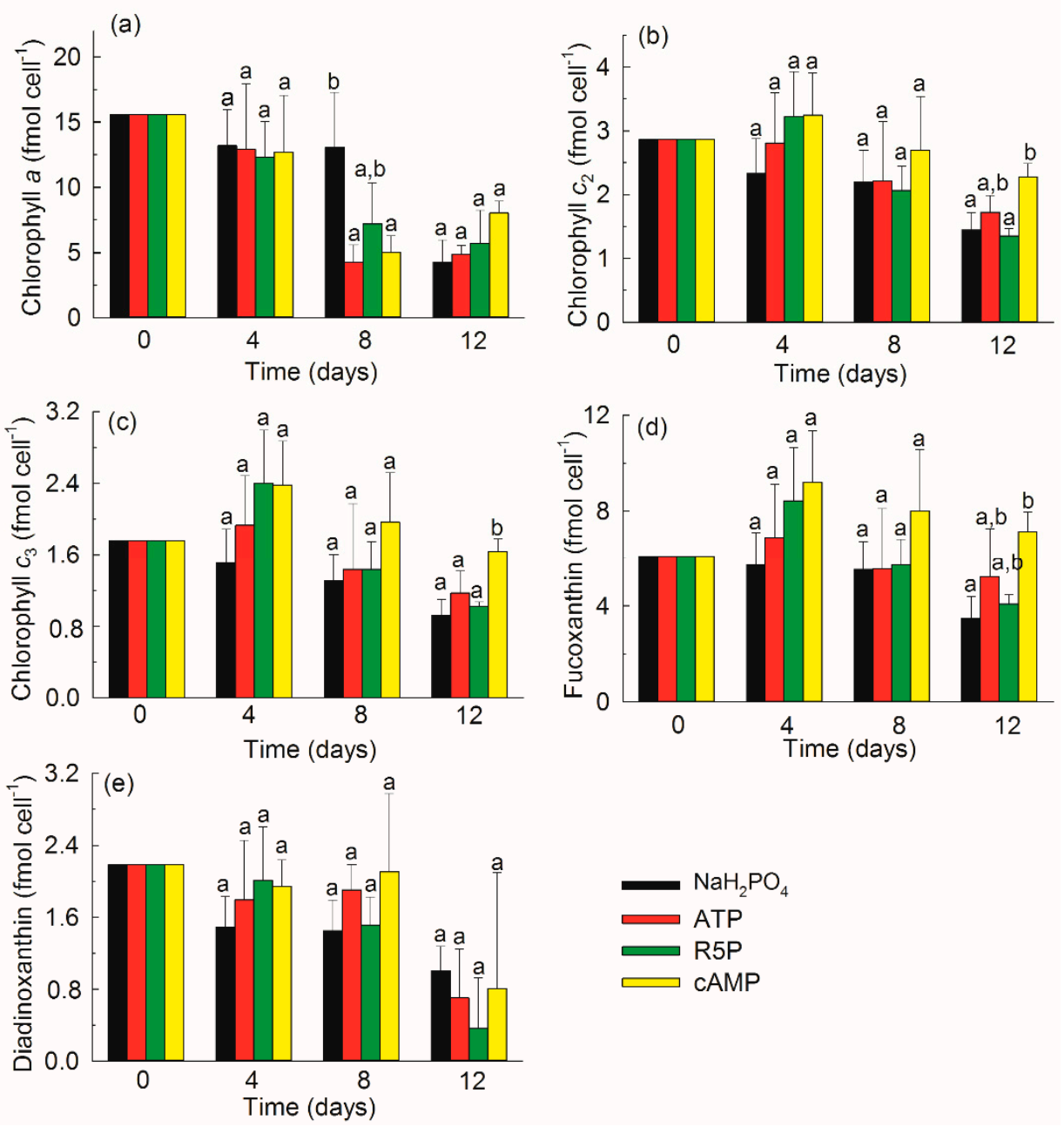

Figure 9. Contents of pigment chlorophyll $a(\mathbf{a})$, chlorophyll $c_{2}(\mathbf{b})$, chlorophyll $c_{3}(\mathbf{c})$, fucoxanthin (d), and diatoxanthin (e) of Karenia mikimotoi in the $\mathrm{NaH}_{2} \mathrm{PO}_{4}$, adenosine triphosphate (ATP), ribulose 5-phosphate (R5P), and cyclic adenosine monophosphate (cAMP) treatments on days $0,4,8$, and 12. The values are the mean \pm S.D. $(n=3)$. Significant differences $(p<0.05)$ among different phosphorus substrates are shown with different lowercase letters.

\subsection{Hemolytic Activity}

The hemolytic activity varied greatly among different treatments and with time (Figure 10). The hemolytic activity in the cAMP treatment was significantly higher than that in any other treatment on day $4(p<0.01)$. The difference in hemolytic activity among different treatments increased on day 8 , and the activity in the cAMP treatment was 2.6, 6.4, and 36.6 times that in the $\mathrm{NaH}_{2} \mathrm{PO}_{4}$, ATP and $\mathrm{R} 5 \mathrm{P}$ treatments, respectively. The hemolytic activity in the DOP substrates decreased, whereas that in the $\mathrm{NaH}_{2} \mathrm{PO}_{4}$ treatment increased on day 12. The activity in the $\mathrm{NaH}_{2} \mathrm{PO}_{4}$ treatment was $2.7-3.7$ times that in any other 
treatment $(p<0.001)$ on day 12 . However, the hemolytic activity increased again in all of the treatments, and the activity was the highest in the cAMP treatment and the lowest in the R5P treatment $(p<0.05)$ on day 16.

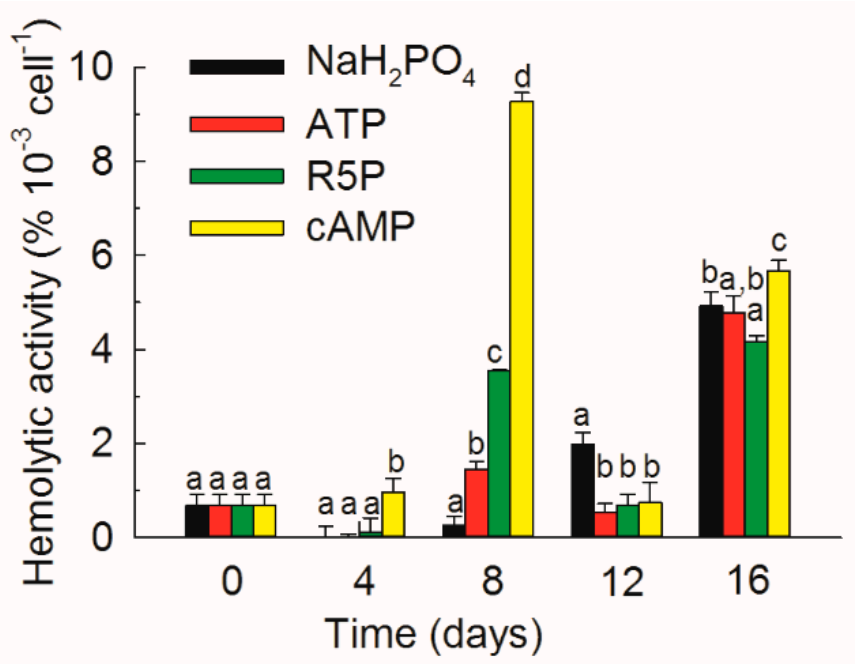

Figure 10. Hemolytic activity of Karenia mikimotoi in the $\mathrm{NaH}_{2} \mathrm{PO}_{4}$, adenosine triphosphate (ATP), ribulose 5-phosphate (R5P), and cyclic adenosine monophosphate (cAMP) treatments on days $0,4,8$, 12 and 16. The values are the mean \pm S.D. $(n=3)$. Significant differences $(p<0.05)$ among different phosphorus substrates are shown with different lowercase letters.

\section{Discussion}

Blooms of K. mikimotoi are often observed in seawater with a high N:P ratio and low phosphate concentration in late spring and summer in the East China Sea [18,23]. The potential of K. mikimotoi to utilize DOP as a substitute P source might be crucial to bloom formation and persistence. The DOP pool in seawater is composed of various compounds with different chemical properties, among which P-esters (PMEs and PDEs) and phosphonates appear to account for $75 \%$ and $25 \%$, respectively $[25,37]$. To date, phosphonates have been shown to be available only to heterotrophic bacteria and some cyanobacteria [26,38]. In the P-ester pool, PMEs are normally the most abundant and available DOP [24,37,39]; however, the concentrations of PDEs are comparable or even higher than those of PMEs in some coastal waters $[25,40,41]$. In the present study, the bioavailability of different forms of PMEs (R5P and ATP) and PDE (cAMP) for the growth of K. mikimotoi was compared with that of inorganic $\mathrm{NaH}_{2} \mathrm{PO}_{4}$. The results indicated that K. mikimotoi successfully utilized the various organic $\mathrm{P}$ compounds for growth, which coincided with previous studies $[27,28]$. It is worth noting that the growth of K. mikimotoi on DOP compounds was comparable to or even better than that on inorganic $\mathrm{NaH}_{2} \mathrm{PO}_{4}$ (Figure $2 b$,c and Figure 3). An environment with limited phosphate but abundant labile DOP might benefit the growth of K. mikimotoi. In addition, the present study also suggested that $K$. mikimotoi is a P storage strategist and is acclimated to external low-phosphate conditions through the efficient utilization of the internal P pool. K. mikimotoi is a slow-growing species [3] and had an average $\mu$ lower than $0.1 \mathrm{~d}^{-1}$ in the present study. The sharp decrease in DIP in the $\mathrm{NaH}_{2} \mathrm{PO}_{4}$ treatment in the first two days indicated a luxury uptake of phosphate by K. mikimotoi (Figure 1a). K. mikimotoi depended on the internal $P$ pool to sustain slow growth and obtained a maximum density on day 10 , which was twice that on day 2 , and then sustained the density and activity thereafter (Figures $2 \mathrm{a}$ and 3 ). Compared with fast-growing diatoms that burst rapidly in eutrophic environments but also collapse rapidly in oligotrophic environments [42], slow-growing K. mikimotoi might be more competitive in environments that vary widely in terms of nutrient availability.

Phosphate is considered the only $\mathrm{P}$ compound that can be taken up directly by phytoplankton [24]. Complex DOP compounds should be hydrolyzed by various phosphatases to release phosphate, which is thus available to phytoplankton [24,43]. Differences were 
observed in the hydrolysis and uptake rates of PMEs and PDE by K. mikimotoi in the present study. The hydrolysis rates of ATP and R5P were comparable but much faster than that of cAMP (Figure 1b), suggesting a longer turnover time of the PDE than the PMEs. This result is explainable, since PDEs should first be degraded by the action of PDEase, and, subsequently, the produced PMEs should be degraded by the action of PMEase $[37,40]$. PDEs are considered biologically more stable than PMEs [25,41]. However, this characteristic of PDEs does not include some biologically labile compounds, such as dissolved DNA that can be cycled in $<1$ day $[40,43]$. In the present study, phosphate hydrolyzed from organic $P$ substrates by phosphatases was quickly consumed by K. mikimotoi. A small increase in the amount of DIP observed in the organic P treatments during days 2-6 suggested that the hydrolysis rates of DOP compounds were even higher than the uptake rate of phosphate (Figure 1a). Organic P compounds were efficiently hydrolyzed.

In natural seawater environments, there are three important classes of P-esterases: APase, 5'-nucleotidase and PDEase [26,37]. Both APase and 5'-nucleotidase can hydrolyze PMEs, and the difference is that APase is nonspecific for a wide range of PMEs, whereas $5^{\prime}$-nucleotidase acts specifically on $5^{\prime}$-nucleotides [24]. To date, APase is probably the most well-studied phosphatase in both field studies and laboratory species studies [26,38,44]. Compared with APase, PDEase is not as well studied but is also likely important in the cycling of PDEs (DNA, RNA, cyclic nucleotides, and lipids) [39,41]. To the best of our knowledge, the present study is the first to investigate the activities of both APase and PDEase in K. mikimotoi. The value of PDEA was comparable to that of APA (Figure 4a,b), suggesting the potential importance of PDEase in hydrolyzing the DOP pool. Bacteria and eukaryotic phytoplankton are the main producers of phosphatases in nature [45]. Richardson and Corcoran [12] found that nonaxenic K. mikimotoi, rather than axenic K. mikimotoi, could utilize PDEs for growth and suggested that K. mikimotoi does not produce PDEase. In the present study, although antibiotics were added in order to eliminate bacteria, the observed picosized phosphatase activities indicated that bacteria still played a role in the hydrolysis of DOP (Figure 4c). However, both nanosized phosphatase activities increased greatly during the whole experiment and contributed more than $65 \%$ of the total phosphatases on average, suggesting that the studied strain of K. mikimotoi could produce not only APase but also PDEase, even considering that some bacteria might have attached to the algal surface. The production of PDEase by eukaryotic phytoplankton has also been observed in some diatoms and raphidophytes [26,37]. In the present study, the relatively high amounts of APA and PDEA produced by K. mikimotoi might indicate a more severe $\mathrm{P}$ stress status of phytoplankton than bacteria in phosphate-deficient media. Compared with phytoplankton, the P stress threshold of smaller bacteria is much lower [46]. The enzyme $5^{\prime}$-nucleotidase is widely present in phytoplankton [26]. Luo et al. [13] suggested that $5^{\prime}$-nucleotidase, rather than APase, is responsible for ATP hydrolysis in K. mikimotoi. Although the activities of $5^{\prime}$-nucleotidase were not measured in the present study, the relatively low values of APA compared with R5P in the ATP treatment (Figure 4a) suggested that not only APase but also 5'-nucleotidase might play roles in the hydrolysis of ATP.

Phosphatases can be divided into constitutive and inducible classes [26,44]. The present study suggested that most APases and PDEases are inducible enzymes that were abundantly expressed by K. mikimotoi under P deficiency. In addition, very low percentages $(<10 \%)$ of both phosphatases in the dissolved fraction were observed in K. mikimotoi during the whole experiment (Figure $4 \mathrm{c}, \mathrm{d}$ ), which was quite different from previously reported results in dinoflagellate species, such as three species of Prorocentrum [44] and Alexandrium catenella [47], which released abundant phosphatase into seawater over time. Thingstad et al. [46] indicated that the liberation of phosphatases to seawater would drive microbes toward pure phosphate competition by preventing hydrolysis-uptake coupling on the cell surface. Thus, maintaining phosphatases on the cell surface is advantageous for K. mikimotoi, allowing this species to directly take up hydrolyzed phosphate without intermediate mixing in the phosphate pool. 
The results of particulate $\mathrm{C}, \mathrm{N}$, and P reflected the capability of K. mikimotoi to hydrolyze and assimilate different forms of $P$ substrates in some way. Cellular stoichiometry is believed to match the environmental nutrient supply at low growth rates [48]. On day 4, when the cell growth among different treatments was comparable, the difference in POP in the organic $P$ treatments (Figure $5 c$ ) reflected much faster assimilation of ATP and R5P than cAMP. The hydrolysis-uptake rate of K. mikimotoi could not meet the P growth demand in the cAMP treatment, and PON:POP increased to 38.6, which is much higher than the $\mathrm{P}$ deficiency threshold of 22 [49]. The significant increase in PON in the cAMP treatment on day 4 (Figure 5b) might reflect the acclimation of K. mikimotoi to produce more proteins or enzymes rich in $\mathrm{N}$ in response to $\mathrm{P}$ deficiency. With the progressive hydrolysis of cAMP to PME and phosphate, the P-deficient status of K. mikimotoi in the cAMP treatment was somehow alleviated, the cells showed decreased needs for specific proteins or enzymes, and the PON also decreased on day 8. The ratio of particulate C:N:P reflected variations in the cellular compound composition because major cellular biomolecules differ in their $\mathrm{C}, \mathrm{N}$, and P contents [50]. Under P deficiency, phytoplankton show reduced contents of ribosomes and RNA, which are rich in P and slow growth [38], and POP decreased greatly in the present study (Figure 5c). Meanwhile, C-rich compounds, such as carbohydrates and triglycerides, are continually synthesized and accumulated by cells under these conditions [50,51], and POC increased in this study, as shown in Figure 5a. In the later period, the much lower content of particulate nutrients in the R5P treatment was due to the higher growth of K. mikimotoi compared with that on other P substrates. K. mikimotoi successfully assimilated different forms of $\mathrm{P}$ substrates, among which R5P might have been the best substrate. In addition, Luo et al. [13] indicated that K. mikimotoi might have the capability to directly transport ATP and its hydrolysis nucleotide products (ADP or AMP) into cells. In the present study, the POC and PON in the ATP treatment did not show higher values than those in the R5P treatment during the exponential phase (days 4 and 8) (Figure 5a,b). Thus, the authors suggest that the major way in which $K$. mikimotoi utilizes ATP as a P source is by taking up phosphate released through hydrolysis by APase or $5^{\prime}$-nucleotidase.

K. mikimotoi is a common HAB species in coastal waters [1,3]. Knowledge of its pigment composition aids in rapid taxonomic identification and accurate biomass quantification [52,53]. Pigment compositions show differences between species and even strains [51]. In the present study, in addition to Chl $a$, fucoxanthin, 19'-butanoyloxyfucoxanthin, and 19' hexanoyloxyfucoxanthin, which are considered the major pigments of K. mikimotoi [53,54], contents of $\mathrm{Chl}_{2}$ and $\mathrm{Chl} c_{3}$ were observed in the studied strain (Figure 7). In addition, trace amounts of zeaxanthin were observed (Figure 6), which is not common to every strain of K. mikimotoi [54]. The ratio between a marker pigment and Chl $a$ is widely used to calculate the contributions of phytoplankton groups to total Chl $a$ [55]. The ratio of a marker pigment fucoxanthin to $\mathrm{Chl} a$ varied greatly from $0.33 \pm 0.03$ to $1.75 \pm 0.93$ (Figure 8), which was influenced by both P deficiency and the growth phase. Thus, caution should be taken when using this diagnostic ratio.

Most studies analyze the role of $\mathrm{N}$ in pigments because $\mathrm{N}$ is the main element in light-harvesting apparatuses [51]. The pigment contents of phytoplankton decrease greatly under $\mathrm{N}$ deficiency $[53,55]$. Additionally, the pigment composition of phytoplankton can change greatly with various $\mathrm{N}$ compounds [56]. The effects of variations in the $\mathrm{P}$ concentration and $\mathrm{P}$ form on the pigment composition and content were analyzed in the present study. The $\mathrm{Chl} a$ content in the $\mathrm{NaH}_{2} \mathrm{PO}_{4}$ treatment on day 8 (Figure 9a), in which K. mikimotoi suffered the most severe P stress (data shown for DIP in Figure 1a and APA in Figure 4a), was significantly higher than that in any other treatment, suggesting that K. mikimotoi tried to increase its photosynthetic capability to address P deficiency. Some pigments, especially $\mathrm{Chl} a$, decreased greatly from the exponential phase to the stationary phase. One explanation is related to the enhanced P stress in the studied strain. Another reason might be that with increasing biomass, the amount of light received by each cell decreases, so the pigment contents also decrease [53]. Different $P$ compounds did not influence the pigment composition or content of K. mikimotoi (Figures 7 and 9). The 
differences in the contents of some accessory pigments ( $\mathrm{Chl} c_{2}, \mathrm{Chl} c_{3}$, and fucoxanthin) in the cAMP treatment on day 12 were due to the relatively slow growth and lower density compared with those in other treatments.

Blooms of K. mikimotoi are connected with fish and shellfish mortality [3,6,7]. Hemolytic activity is a key factor in the toxic potential of $K$. mikimotoi [3,4]. A connection between $P$ deficiency and enhanced cell toxicity has been observed in K. mikimotoi [57], and some other dinoflagellates, such as Alexandrium fundyense [58], and Karlodinium veneficum [59]. However, in the present study, it seemed that the different $\mathrm{P}$ forms rather than $\mathrm{P}$ concentrations determined the amount of hemolytic activity in K. mikimotoi during the exponential phase. The hemolytic activity in the presence of organic $\mathrm{P}$ substrates, especially the relatively refractory cAMP, was significantly higher than that in the $\mathrm{NaH}_{2} \mathrm{PO}_{4}$ treatment (Figure 10). It is uncertain whether there is coupling between DOP hydrolysis and hemolytic activity. $\mathrm{Li}$ et al. [17] indicated that K. mikimotoi was more toxic in the exponential phase than the stationary phase. However, in the present study, hemolytic activity reached a high value during the stationary phase on day 16 (Figure 10). One possible explanation is that severe $P$ stress or limitation induced this species to increase hemolytic activity.

\section{Conclusions}

The frequency of K. mikimotoi blooms has increased greatly in recent decades in East Asia [9]. Meanwhile, the nutrient structure in coastal waters has changed from $\mathrm{N}$ deficiency to $P$ deficiency, especially during the periods of spring and summer when K. mikimotoi blooms occur $[18,21,23]$. The potential advantage of K. mikimotoi in utilizing substitute DOP compounds might be crucial in interspecific competition in phytoplankton communities in phosphate-depleted environments.

PMEs and PDEs are the most abundant organic $P$ available to phytoplankton $[25,38]$. Our studies confirmed that K. mikimotoi could produce both APase and PDEase to hydrolyze DOP compounds. In particular, the quantity and response rate of PDEase were comparable to those of APase, suggesting the potential importance of PDEs as available $\mathrm{P}$ sources. Furthermore, the growth and photosynthetic activity of K. mikimotoi grown on organic P compounds were comparable to or even higher than those of K. mikimotoi grown on inorganic phosphate, which suggested that organic $\mathrm{P}$ is a good nutrient source for K. mikimotoi. K. mikimotoi even produced higher hemolytic activity in the presence of DOP compounds. The present study revealed the strong capability of K. mikimotoi to utilize organic $\mathrm{P}$ compounds through phosphatases, and thus suggested considering the role of organic $\mathrm{P}$ in nutrient dynamics when evaluating the underlying mechanism of K. mikimotoi blooms.

Author Contributions: K.H.: Methodology; Validation; Writing: original and revised draft. Y.Z:: Investigation; Formal analysis; Visualization. Z.W.: Investigation; Data curation. L.O.: Methodology; Supervision; Project administration; Writing: original and revised draft. J.C.: Resources. S.L.: Writing: review \& editing. Y.Q.: Writing: review \& editing. All authors have read and agreed to the published version of the manuscript.

Funding: This work was supported by the National Science Foundation of China [grant numbers 41776121 and 42176201].

Institutional Review Board Statement: Not applicable.

Data Availability Statement: The data that support the findings of this study are available from the corresponding author upon reasonable request.

Acknowledgments: The authors thank Lei Wang from the Third Institute of Oceanography, Ministry of Natural Resources for the help in analysis of pigment data.

Conflicts of Interest: We declare no conflicts of interest. 


\section{References}

1. Brand, L.E.; Campbell, L.; Bresnan, E. Karenia: The biology and ecology of a toxic genus. Harmful Algae 2012, 14, 156-178. [CrossRef]

2. Townhill, B.L.; Tinker, J.; Jones, M.; Pitois, S.; Creach, V.; Simpson, S.D.; Dye, S.; Bear, E.; Pinnegar, J.K. Harmful algal blooms and climate change: Exploring future distribution changes. ICES J. Mar. Sci. 2018, 75, 1882-1893. [CrossRef]

3. Li, X.D.; Yan, T.; Yu, R.C.; Zhou, M.J. A review of Karenia mikimotoi: Bloom events, physiology, toxicity and toxic mechanism. Harmful Algae 2019, 90, 101702. [CrossRef] [PubMed]

4. Kim, D.; Li, W.C.; Matsuyama, Y.; Matsuo, A.; Yagi, M.; Cho, K.; Yamasaki, Y.; Takeshita, S.; Yamaguchi, K.; Oda, T. Straindependent lethal effects on abalone and haemolytic activities of the dinoflagellate Karenia mikimotoi. Aquaculture 2020, $520,734953$. [CrossRef]

5. Ohkubo, N.; Tomaru, Y.; Yamaguchi, H.; Kitatsuji, S.; Mochida, K. Development of a method to assess the ichthyotoxicity of the harmful marine microalgae Karenia spp. using gill cell cultures from red sea bream (Pagrus major). Fish Physiol. Biochem. 2017, 43, 1603-1612. [CrossRef]

6. Kim, D.; Li, W.C.; Matsuyama, Y.; Cho, K.; Yamasaki, Y.; Takeshita, S.; Yamaguchi, K.; Oda, T. Extremely high level of reactive oxygen species (ROS) production in a newly isolated strain of the dinoflagellate Karenia mikimotoi. Eur. J. Phycol. 2019, 54, 632-640. [CrossRef]

7. Aoki, K.; Yamatogi, T.; Hirae, S.; Yamamoto, K.; Yoshida, K.; Muta, K. Increased occurrence of red-tides of fish-killing dinoflagellate Karenia mikimotoi and related environmental conditions in Imari Bay, Japan. Reg. Stud. Mar. Sci. 2020, 39, 101470. [CrossRef]

8. Chen, B.H.; Wang, K.; Guo, H.G.; Lin, H. Karenia mikimotoi blooms in coastal waters of China from 1998 to 2017. Estuar. Coast. Shelf Sci. 2021, 249, 107034.

9. Sakamoto, S.; Lim, W.A.; Lu, D.D.; Dai, X.F.; Orlova, T.; Iwataki, M. Harmful algal blooms and associated fisheries damage in East Asia: Current status and trends in China 2017, Japan, Korea and Russia. Harmful Algae 2021, 102, 101787. [CrossRef] [PubMed]

10. Ministry of Natural Resource of the People's Republic of China (MNR). Bulletin of China Marine Disaster in 2017; Department of Marine Early Warning and Monitoring of MNR: Beijing, China, 2018.

11. Aoki, K.; Kameda, T.; Yamatogi, T.; Ishida, N.; Hirae, S.; Kawaguchi, M.; Syutou, T. Spatio-temporal variations in bloom of the red-tide dinoflagellate Karenia mikimotoi in Imari Bay 2017, Japan, in 2014: Factors controlling horizontal and vertical distribution. Mar. Pollut. Bull. 2017, 124, 130-138. [CrossRef]

12. Richardson, B.; Corcoran, A.A. Use of dissolved inorganic and organic phosphorus by axenic and nonaxenic clones of Karenia brevis and Karenia mikimotoi. Harmful Algae 2015, 48, 30-36. [CrossRef]

13. Luo, H.; Lin, X.; Li, L.; Lin, L.X.; Zhang, C.; Lin, S.J. Transcriptomic and physiological analyses of the dinoflagellate Karenia mikimotoi reveal non-alkaline phosphatase-based molecular machinery of ATP utilization. Environ. Microbiol. 2017, 19, 4506-4518. [CrossRef]

14. Yuasa, K.; Shikata, T.; Kuwahara, Y.; Nishiyama, Y. Adverse effects of strong light and nitrogen deficiency on cell viability photosynthesis, and motility of the red-tide dinoflagellate Karenia mikimotoi. Phycologia 2018, 57, 525-533. [CrossRef]

15. Huang, K.X.; Feng, Q.L.; Zhang, Y.; Ou, L.J.; Cen, J.Y.; Lu SHQi, Y.Z. Comparative uptake and assimilation of nitrate, ammonium, and urea by dinoflagellate Karenia mikimotoi and diatom Skeletonema costatum s.l. in the coastal waters of the East China Sea. Mar. Pollut. Bull. 2020, 155, 111200. [CrossRef]

16. Niu, X.Q.; Xu, S.N.; Yang, Q.Y.; Xu, X.L.; Zheng, M.M.; Li, X.; Guan, W.C. Toxic effects of the dinoflagellate Karenia mikimotoi on zebrafish (Danio rerio) larval behavior. Harmful Algae 2021, 103, 101996. [CrossRef] [PubMed]

17. Li, Y.; Yu, J.; Sun, T.; Liu, C.; Sun, Y.; Wang, Y. Using the marine rotifer Brachionus plicatilis as an endpoint to evaluate whether ROS-dependent hemolytic toxicity is involved in the allelopathy induced by Karenia mikimotoi. Toxins 2018, 10, 439. [CrossRef] [PubMed]

18. Li, J.; Glibert, P.M.; Zhou, M.J.; Lu, S.H.; Lu, D.D. Relationships between nitrogen and phosphorus forms and ratios and the development of dinoflagellate blooms in the East China Sea. Mar. Ecol. Prog. Ser. 2009, 383, 11-26. [CrossRef]

19. Barnes, M.K.; Tilstone, G.H.; Smyth, T.J.; Widdicombe, C.E.; Gloël, J.; Robinson, C.; Kaiser, J.; Suggett, D.J. Drivers and effects of Karenia mikimotoi blooms in the western English Channel. Prog. Oceanogr. 2015, 137, 456-469. [CrossRef]

20. Glibert, P.M.; Burford, M.A. Globally changing nutrient loads and harmful algal blooms: Recent advances, new paradigms, and continuing challenges. Oceanography 2017, 30, 58-69. [CrossRef]

21. Liu, X.; Xiao, W.P.; Landry, M.R.; Chiang, K.P.; Wang, L.; Huang, B.Q. Responses of phytoplankton communities to environmental variability in the East China Sea. Ecosystems 2016, 19, 832-849. [CrossRef]

22. Moon, J.Y.; Lee, K.; Lim, W.A.; Lee, E.; Dai, M.H.; Choi, Y.H.; Han, I.S.; Shin, K.; Kim, J.M.; Chae, J. Anthropogenic nitrogen is changing the East China and Yellow seas from being N deficient to being P deficient. Limnol. Oceanogr. 2020, 66, 914-924.

23. Song, S.; Li, Z.; Li, C.; Yu, Z. The response of spring phytoplankton assemblage to diluted water and upwelling in the eutrophic Changjiang (Yangtze River) Estuary. Acta Oceanol. Sin. 2017, 36, 101-110. [CrossRef]

24. Cembella, A.D.; Antia, N.J.; Harrison, P.J. The utilization of inorganic and organic phosphorous compounds as nutrients by eukaryotic microalgae: A multidisciplinary perspective: Part 1. Crit. Rev. Microbiol. 1984, 10, 317-391. [CrossRef] [PubMed]

25. Suzumura, M.; Ishikawa, K.; Ogawa, H. Characterization of dissolved organic phosphorus in coastal seawater using ultrafiltration and phosphohydrolytic enzymes. Limnol. Oceanogr. 1998, 43, 1553-1564. [CrossRef] 
26. Dyhrman, S.T. Nutrient and Their Acquisition: Phosphorus Physiology in Microalgae. In The Physiology of Microalgae; Borowitzka, M.A., Beardall, J., Raven, J.A., Eds.; Springer: Berlin/Heidelberg, Germany, 2016; Volume 159, pp. $159-187$.

27. Yamaguchi, M.; Itakura, S. Nutrition and growth kinetics in nitrogen- or phosphorus-limited cultures of the noxious red tide dinoflagellate Gymnodinium mikimotoi. Fish. Sci. 1999, 65, 367-373. [CrossRef]

28. Yamaguchi, H.; Nishijima, T.; Nishitani, H.; Fukami, K.; Adach, M. Organic phosphorus utilization and alkaline phosphatase production of 3 red tide phytoplankton. Nippon Suisan Gakkai Shi 2004, 70, 123-130. (In Japanese with an English abstract) [CrossRef]

29. Sunda, W.G.; Price, N.M.; Morel, F.M.M. Trace metal ion buffers and their use in culture studies. In Algal Culturing Techniques; Andersen, R.A., Ed.; Academic Press: Cambridge, MA, USA, 2005; pp. 35-64.

30. Guillard, R.R.L. Culture of phytoplankton for feeding marine invertebrates. In Culture of Marine Invertebrate Animals; Smith, W.L., Chanley, M.H., Eds.; Plenum Press: New York, NY, USA, 1975; pp. 26-60.

31. Valderrama, J.C. Methods of nutrient analysis. In Manual on Harmful Marine Microalgae; Hallegraeff, G.M., Anderson, D.M., Cembella, A.D., Eds.; UNESCO Publ.: Paris, France, 1995; pp. 251-568.

32. Jeffries, D.S.; Dieken, F.P.; Jones, D.E. Performance of the autoclave digestion method for total phosphorus analysis. Water Res. 1979, 13, 275-279. [CrossRef]

33. Solórzano, L.; Sharp, J. Determination of total dissolved phosphorus and particulate phosphorus in natural waters. Limnol. Oceanogr. 1980, 25, 754-758. [CrossRef]

34. Yamaguchi, H.; Yamaguchi, M.; Fukami, K.; Adachi, M.; Nishijima, T. Utilization of phosphate diester by the marine diatom Chaetoceros ceratosporus. J. Plankton Res. 2005, 27, 603-606. [CrossRef]

35. Zapata, M.; Rodriguez, F.; Garrido, J.L. Separation of chlorophylls and carotenoids from marine phytoplankton a new HPLC method using a reversed phase C8 column and phridine-containing mobile phases. Mar. Ecol. Prog. Ser. 2000, 195, 29-45. [CrossRef]

36. Eschbach, E.; Scharsack, J.P.; John, U.; Medlin, L.K. Improved erythrocyte lysis assay in microtitre plates for sensitive detection and efficient measurement of haemolytic compounds from ichthyotoxic Algae. J. Appl. Toxicol. 2001, 21, 513-519. [CrossRef]

37. Yamaguchi, H.; Arisaka, H.; Otsuka, N.; Tomaru, Y. Utilization of phosphate diesters by phosphodiesterase-producing marine diatoms. J. Plankton Res. 2014, 36, 281-285. [CrossRef]

38. Lin, S.J.; Litaker, R.W.; Sunda, W.G. Phosphorus physiological ecology and molecular mechanisms in marine phytoplankton. J. Phycol. 2016, 52, 10-36. [CrossRef]

39. Yamaguchi, T.; Sato, M.; Hashihama, F.; Ehama, M.; Shiozaki, T.; Takahashi, K.; Furuya, K. Basin-scale variations in labile dissolved phosphoric monoesters and diesters in the central North Pacific Ocean. J. Geophys. Res. Ocean. 2019, 124, 3058-3072. [CrossRef]

40. Sato, M.; Sakuraba, R.; Hashihama, F. Phosphate monoesterase and diesterase activities in the North and South Pacific Ocean. Biogeosciences 2013, 10, 7677-7688. [CrossRef]

41. Yamaguchi, T.; Sato, M.; Gonda, N.; Takahashi, K.; Furuya, K. Phosphate diester utilization by marine diazotrophs Trichodesmium erythraeum and Crocosphaera watsonii. Aquat. Microb. Ecol. 2020, 85, 211-218. [CrossRef]

42. Smayda, T.J. Harmful algal blooms: Their ecophysiology and general relevance to phytoplankton blooms in the sea. Limnol. Oceanogr. 1997, 42, 1137-1153. [CrossRef]

43. Ou, L.J.; Huang, X.Y.; Huang, B.Q.; Qi, Y.Z.; Lu, S.H. Growth and competition for different forms of organic phosphorus by the dinoflagellate Prorocentrum donghaiense with the dinoflagellate Alexandrium catenella and with the diatom Skeletonema costatum s.l. Hydrobiologia 2015, 754, 29-41. [CrossRef]

44. Ou, L.J.; Qin, X.L.; Shi, X.Y.; Feng, Q.L.; Zhang, S.W.; Lu, S.H.; Qi, Y.Z. Alkaline phosphatase activities and regulation in three harmful Prorocentrum species from the coastal waters of East China Sea. Microb. Ecol. 2020, 79, 459-471. [CrossRef] [PubMed]

45. Hoppe, H.G. Phosphatase activity in the sea. Hydrobiologia 2003, 493, 187-200. [CrossRef]

46. Thingstad, T.F.; Havskum, H.; Garde, K.; Riemann, B. On the strategy of "eating your competitor": A mathematical analysis of algal mixotrophy. Ecology 1993, 77, 2108-2118. [CrossRef]

47. Ou, L.J.; Huang, B.Q.; Hong, H.S.; Qi, Y.Z.; Lu, S.H. Comparative alkaline phosphatase characteristics of the algal bloom species Prorocentrum donghaiense, Alexandrium catenella and Skeletonema costatum. J. Phycol. 2010, 46, 260-265. [CrossRef]

48. Moreno, A.R.; Martiny, A.C. Ecological stoichiometry of ocean plankton. Annu. Rev. Mar. Sci. 2018, 10, 43-69. [CrossRef]

49. Hecky, R.E.; Campbell, P.; Hendzel, L.L. The stoichiometry of carbon, nitrogen, and phosphorus in particulate matter of lakes and oceans. Limnol. Oceanogr. 1993, 38, 709-724. [CrossRef]

50. Grosse, J.; van Breugel, P.; Brussaard, C.P.D.; Boschker, H.T.S. A biosynthesis view on nutrient stress in coastal phytoplankton. Limnol. Oceanogr. 2017, 62, 490-506. [CrossRef]

51. Tanioka, T.; Matsumoto, K. A meta-analysis on environmental drivers of marine phytoplankton C.:N:P. Biogeosciences 2020, 17, 2939-2954. [CrossRef]

52. Schlüter, L.; Møhlenberg, F.; Havskum, H.; Larsen, S. The use of phytoplankton pigments for identifying and quantifying phytoplankton groups in coastal areas: Testing the influence of light and nutrients on pigment/chlorophyll $a$ ratios. Mar. Ecol. Prog. Ser. 2000, 192, 49-63. [CrossRef]

53. Dizaji, S.Z.; Fariman, G.A.; Zahedi, M.M. Pigment content analysis in two HAB forming dinoflagellate species during the growth period. J. Appl. Phycol. 2021, 33, 807-817. [CrossRef] 
54. Chang, F.H.; Gall, M. Pigment compositions and toxic effects of three harmful Karenia species, Karenia concordia, Karenia brevisulcata and Karenia mikimotoi (Gymnodiniales, Dinophyceae), on rotifers and brine shrimps. Harmful Algae 2013, 27, 113-120. [CrossRef]

55. Descy, J.P.; Sarmento, H.; Higgins, H.W. Variability of phytoplankton pigment ratios across aquatic environment. Eur. J. Phycol. 2009, 44, 319-330. [CrossRef]

56. Ou, L.J.; Cai, Y.Y.; Jin, W.Y.; Wang, Z.; Lu, S.H. Understanding the nitrogen uptake and assimilation of the Chinese strain of Aureococcus anophagefferens (Pelagophyceae). Algal Res. 2018, 34, 182-190. [CrossRef]

57. Wang, X.J.; Feng, X.Q.; Zhuang, Y.; Lu, J.H.; Wang, Y.; Gonçalves, R.J.; Li, X.; Lou, Y.L.; Guan, W.C. Effects of ocean acidification and solar ultraviolet radiation on physiology and toxicity of dinoflagellate Karenia mikimotoi. Harmful Algae 2019, 81, 1-9. [CrossRef] [PubMed]

58. John, E.H.; Flynn, K.J. Growth dynamics and toxicity of Alexandrium fundyense (Dinophyceae): The effect of changing N:P supply ratios on internal toxin and nutrient levels. Eur. J. Phycol. 2000, 35, 11-23. [CrossRef]

59. Fu, F.; Place, A.R.; Garcia, N.S.; Hutchins, D.A. $\mathrm{CO}_{2}$ and phosphate availability control the toxicity of the harmful bloom dinoflagellate Karlodinium veneficum. Aquat. Microb. Ecol. 2010, 59, 55-65. [CrossRef] 